УДК 821.111-31.09”18/19”Девід Гаскойн

\title{
POETRY OR POÉSIE? DAVID GASCOYNE'S “CONCEPT OF POETRY AS A VEHICLE FOR THE EXPRESSION OF SPIRITUAL ACTIVITY”
}

\author{
Tobiasz Cwynar \\ Warsaw University of Technology \\ 1, Pl. Politechniki, Warsaw, Poland, 00-661 \\ Wszechnica Polska in Warsaw \\ 1, Pl. Defilad, Warsaw, Poland, 00-901 \\ tobiaszcwynar@gmail.com
}

The paper seeks to provide a short introduction to the understanding of the nature, the role and the scope of poetry found in David Gascoyne's écriture. It presents the main features of poetry construed not as a craft, nor merely as a means of expression, but as an authentic spiritual activity (another notion of capital importance for the English poet's writings which constitutes a subject of the paper), and contextualizes it with a brief analysis of what is the main influence on David Gascoyne's thought in this respect - that is to say, the dadaist and surrealist theories of poetry as espoused by André Breton - as well as with what the English poet regards as the crucial difference between the specifically "English" definition of poetry and that which, he argues, has come to be meant by poésie in France. The present paper focuses on the self-decentring and self-transcending character of the kind of poetry/poésie David Gascoyne self-avowedly practices and endorses.

Keywords: surrealism, modernism, spirituality, existential, existentialism

The standard designation literary critics assign to David Gascoyne, a surrealist intellectuel who expands the project initiated by André Breton onto the terrain traditionally reserved for existential philosophy, is that of an English poet - a dangerous phrase, for Gascoyne's poetry, to put it bluntly, is not what is usually meant by the word; it is not what the noun has been traditionally used to express, that is, if one accepts and follows the poet's own understanding of what he believes his vocation consists in: "That poetry represents a special, indeed essential category of thought is an idea that since the death of Heidegger, who gave increasing credence in his later writings to this conception, is at present beginning to appear after all to be a proposition worthy of serious consideration by all thinkers, however rational", he submits [30, p. 187] before suggesting, indeed just as Martin Heidegger would, that it is poetry which enables us, or at least ought to make it possible for us, to "question what thinking itself is". Another text most helpful here may be "On the State of Poetry", the article which Gascoyne originally published in and whose substantial part is devoted to an appreciation of the "cogent" [27, p. 67] insights of Real Presences, "George Steiner's latest book" [27, p. 67] - which, the poet claims, "can be considered 'required reading' for all those concerned with the quandaries of language, especially as used by the poets, at the present time", and which "[...] also has exceptional pertinence to any consideration of poetry at the end of the 1980s on account of its courageously unequivocal statement that "any thesis that would, either theoretically or practically put literature and the arts beyond good and evil is spurious". Steiner

(C) T. Cwynar, 2017 
continues: "The archaic torso in Rilke's famous poem says to us: 'change your life'. So do any poem, novel, play, painting, musical composition worth meeting”. Early last October, a weekend newspaper quoted in its "Sayings of the Week" column an observation of John Ashbery: "There is the view that poetry should improve your life. I think people confuse it with the Salvation Army". I was reminded by this witticism of Rilke's archaic torso, and wondered whether the difference between change and improvement could be dismissed as merely a matter of semantics. I was led on to ask myself whether the concept of poetry as a vehicle for the expression of spiritual activity is in fact destined to become as archaic as the torso of Rilke's poem [my italics].

If the uncertainty Gascoyne expresses here - his uncertainty not only about the future of that "concept of poetry" which he, just like Steiner, manifestly subscribes to (the essay's final paragraphs establish it beyond a shadow of a doubt) but also, it appears, about the validity of what he refers to (not without some spite) as "this witticism" of Ashbery's - is characteristic of the English poet's attitude in general, even more trademark must beyond the shadow of a doubt be his understanding of "poetry as a vehicle for the expression of spiritual activity", that human "activity", that is to say, whose "actual" purpose and raison d'être is to substantially "change [our] life", as the title "archaic torso" of the Olympian deity seems to order us to do in Rilke's legendary "Archaic Torso of Apollo". The transformative influence such "poetry" exerts, goes without saying, could be only secondarily aesthetic (Gascoyne insists that Herbert "is not a poet whom one can read purely for aesthetic satisfaction" [21, p. 6], nor can "be approached solely by means of Dr. $<$ I. A.> Richards's popular method of 'suspending belief', that kind of Husserlian bracketing, which can convert no matter what poem to the accessibility of a phenomenon", nor ought to be appreciated "merely for his formal felicities and his "delightful quaintness"": "To read Herbert with a cynical 'however intelligent detachment, as though it were a purer poetry' (as indeed it is) is to fail to appreciate all that is most essential in it Herbert", who instead "should be read with a mind prepared to surrender wholeheartedly to the human appeal of his lines, to respond sincerely, that is to say with an unequivocal acceptance or rejection, to the Christian pleading that is so eloquent in most of his best poems") - its prime scope will lie elsewhere, entirely outside of what Gascoyne will scornfully dismiss as "belles-lettres" [20, p. vii]. Or say the signature aesthetic experience of the "poetry" Gascoyne prizes and writes is the experience of transcending the (merely) aesthetic, the experience in the course of which the aesthetic turns out to be inwardly corroded or infected by, or yet reveals itself as, the (genuinely) existential: Gascoyne recalls that he and the legendary Beat poet shared a love for the art of Cézanne's and the existential thought of Martin Buber, both of whom, he confesses, "influenced me profoundly" [11, p. 113] - and instantly adds: "All the difference between the aesthetic and the ethical, someone might ineptly interject, but I'm sure we could soon talk that distinction away". Such an interpretation could surely explain the significance of the words which, when describing with the greatest admiration the influence which the poetry of Benjamin Fondane exerts, Gascoyne chooses to quote from the latter's response to the écriture of their shared poetical maitre, Arthur Rimbaud - the words which one might so very well echo if one wanted to evoke the influence exerted by Gascoyne's own writings:

"In Rimbaud le voyou, which of all his prose works is perhaps the best known, Benjamin Fondane wrote: "Rimbaud's poetry moves and overwhelms me; it seizes my very entrails". It is precisely this that Fondane's poetry can achieve when he has finished discoursing - done in the most fascinating manner - on the poet's need for reality. It takes hold at the centre of our being, it sends a shiver down the spine, it makes the nerves quiver [...]. In English we speak of a "haunting refrain". Benjamin Fondane often produces in me precisely that effect with his poems. To give 
an example, I immediately think of "The Song of the Emigrant" which can be found in Ulysse. Perhaps inevitably because of the similarity of the titles, the poem makes me think of Apollinaire's "The Song of the Emigrant from Landor Road"; but the relationship, if there is one, is surely the mark of a kind of deep brotherhood. The two poems produce an enchantment capable, in certain circumstances, of taking you by the throat" [28, p. 174].

In any case, Gascoyne is clearly convinced that all "poetry" that is to be a genuine "vehicle for the expression of spiritual activity" must above all be concerned with, as well as capable of addressing, and, if it proves possible, efficaciously transmuting, the existential situation of a person - and to the extent it fails to transcend its being mere "literature", the kind of "poetry" spoken of here will be only but a travesty of itself, yet another "result of an absurd, all-too-human feebleness of mind", as the poet phrases it [19, p. 168]: "Poetry", André Breton confesses [6, p. 83], the much-discussed essay which he originally published in 1922 (and which Gascoyne must have read in the early 1930s), "would hold no interest for me whatsoever if I didn't expect it to suggest to me and some of my friends a specific solution to the problem of our lives" - and what he thus communicates is an attitude towards all writing (and not merely towards that which has been traditionally regarded as poetry in the West) as well as all art which the English poet will all his life embrace and advocate.

It is hardly a whim of mine to quote here from the leader of the French surrealists for, bluntly speaking, Gascoyne's philosophy - or, to be perhaps more exact, philosophies - of poetry are of surrealist provenance (even if they will occasionally lead surrealist thought to somewhat unexpected or remote regions: for instance, the English poet's literary or, better, poetic theory is also massively indebted to Martin Heidegger's post-War writings). To begin with, André Breton is obviously a major and lasting influence on Gascoyne - especially, though by no means solely so, in all the matters relating to the role and character of "poetry". But, more importantly, the way in which the English poet characterizes "the concept of poetry as a vehicle for the expression of spiritual activity" in "On the State of Poetry" not only happens to echo to a significant extent the views on the subject he expressed more than half a century earlier, months before his "beginning to become a disaffected member of the British branch of the Surrealist movement", as he puts [34, p. 297] - in the lecture Gascoyne delivered to the Oxford Union in December 1936 he contrasts "poetry-means-of-expression" [14, p. 27] with what he terms "poetry-activity-of-the-mind", the former being the category which all "descriptive, moralistic or propaganda poetry" falls under while the latter, "superior as poetry to 'poetry-means-of-expression", constitutes nothing less than "the true end towards which all the most vital poetry of the past has been progressing" as well "provides the largest number of possibilities for the future - that is to say for post-revolutionary society" - but as will be seen is also very close to being a veritable reiteration of what Gascoyne has to say on the subject (of the "poetry" whose pursuit he pledges to commit his life to) after that which Rémy describes as the mysterious "fracture d'ordre idéologique, sinon spirituel" [41, p. 14] responsible for the poet's gradual drifting apart from the pursuits of the London-based British "Surrealist group" [12, p. 73] and throwing himself into "une exploration renouvelée de l'inconscient, taraudé par l'idée de la Faute et par l'impasse, ici et maintenant, de la vie de l'homme" [41, p. 14] has come to pass. Once the critical event had taken place, Rémy explains, Gascoyne "was then able to reorientate himself towards a poetic that sought for its own spirituality by a combination of influences" [43, p. 125].

The French critic's words, carefully chosen and once again most admirably apt, bring to mind another spot-on observation - one which Peter Levi makes in his review of David Gascoyne's 
Selected Poems. Discussing Gascoyne's poetic ceuvre, Levi highlights and praises what he calls the English poet's unique "ability to imbibe the essence of another poet and produce it as his own: he has been through this mysterious process with Eluard [sic], Jouve, Eliot, Wallace Stevens" [37] - the statement whose phrasing can hardly fail to recall Gascoyne's Sun at Midnight aphorisms and their exposition of "alchemy" [33, p. 29] as a "process" of "mysterious potency" and "transmutati[ve]" [33, p. 27] power, the "process" which, when its "vessel" is "[p]oetry" $[33$, p. 5], consists "among other things" in "the concentration of imaginative essences" (just as "philosophy is the concentration of wisdoms"), and which always works through, in and with endlessly varying transformations of "a sublime, though divinely poisonous tincture, which produces the final gold of the philosophers, who learnt how not to laugh, nor weep, nor yet detest, but to understand" [33, p. 39]. What both Rémy (who, it ought to be pointed out, is just as interested in "imbibing the essence" of Gascoyne - of Gascoyne "le poète de la Pensée, c'est-a-dire le poète de l'effort de l'homme pour comprendre l'univers" [41, p. 110] as well as of Gascoyne "le penseur de la poésie, c'est-à-dire de la pauvreté comme de l'urgence de toute écriture", the two faces of the English intellectuel being ultimately quite inseparable - in order to "produce it as his own" as I must be preoccupied with "imbibing" it so as to "produce" it as mine) and Levi appear to be suggesting here, then, is that the "spiritual" character of Gascoyne's "poetic" is most intimately connected to its alchemical nature - that, in other words, it "s[eeks] for its own spirituality" by means of an "alchemy" of "influences". It is not only that the "mysterious process" of that "poetic" lends itself, and easily so, to be compared to an alchemical drama (whether unconsciously or, as it often appears, quite consciously indeed, Gascoyne the poet "produce[s]" what could be seen as his "essence" by "imbibing", "combin[ing]" and transmuting the "essence[s]" of his "poetic" models - or, to use a much more fitting word here, "influences"); that which the two passages from Rémy's and Levi's writings I quoted above curiously abound in is the trademark vocabulary of traditional alchemy ("spirituality", "essence", "imbibe" and "produce"), the vocabulary which the poet himself constantly makes use of as well - and which helps him present his "poetic" travails as a Mercurial Opus whose materia prima undoubtedly includes, even if not consists solely in, his numerous "influences." The notion of Gascoyne's poetry being not only a basically alchemical endeavour but also one that ceaselessly involves an alchemy of its "influences" is crying at this point for some more sustained attention - but so is Michel Rémy's seemingly indiscriminate use of the words "poetic" and "poetry", which must be addressed first.

Speaking of Gascoyne's écriture, Rémy does appear to use the two words almost interchangeably. The French critic observes that writing Hölderlin's Madness in 1938 gave the poet a chance "to plumb the depths of despair, as Hölderlin had done, and try to find new poetic directions" [43, p. 125]. That "poetic" descensus ad inferos in turn allowed Gascoyne to "reorientate himself towards" the "poetic that sought for its own spirituality by a combination of influences" - and eventually resulted in his "poetry becom[ing] an unrelenting epidermic search for its own essence, for a prophetic quality, religious in the widest sense of the word, a quest for a synthesis that would mean spiritual revolution," and in this way turning into a venture "in no way remote from the surrealist quest for the 'supreme point,' but," Rémy claims, "with totally opposite means". What might appear to be unnecessary confusion points, I believe, towards the ultimate futility of striving to separate "poetry" from (the) "poetic" - the futility which is a given for both Rémy and Gascoyne. The two words may not be quite synonymous; Rémy leaves the term "poetic" entirely undefined, which is why the relation between the twin terms must remain ultimately elusive, too - what does seems pretty certain, though, is that both the 
fluid boundaries and the self-reflexive fold are very much a part of the nature of each of them. One could wonder at that point the field of "poetry" and (the) "poetic" does not cover poetics as well: Linda Hutcheon imagines poetics as "[...] an open, ever-changing theoretical structure by which to order both our cultural knowledge and our critical procedures. This would not be a poetics in the structuralist sense of the word, but would go beyond the study of literary discourse to the study of cultural practice or theory. As Tzvetan Todorov realized, in a later expanding and translating of his 1968 Introduction to Poetics: "Literature is inconceivable outside a typology of discourses" [36, p. 14].

The boundaries of "the study of literary discourse" are thus opened so that the space of poetics becomes that of "the study of cultural practice or theory" - in fact, more than being "the study of cultural practice or theory [my italics]", it "must deal with both" [36, p. 19], and necessarily so: "[a]rt and theory about art (and culture) should be part of it", certainly, but being a response to the awareness "of the dangers of separating messy practice from neat theory", such poetics "would not set up a hierarchy that might privilege either theory or practice" [36, p. 53]. Being a "cultural practice or theory" (or, rather, both) - and often a part "of literary discourse" as well - itself, it must both "constitute and contain" what it deals with, contriving, exploring and embracing "our discourses about it and adjacent to it" [36, p. ix] just the same. In the context of Gascoyne's writings, so envisioned poetics would - as Rémy's words seem to imply - too find itself concerned with the ambivalent, self-exceeding exploration of the tension between the praxis and the theory that could possibly be seeking to objectify it; between the transforming shape and both the space, hypothetical or otherwise, which the former supposedly seeks to test, rewrite or give expression to and that which the relation between the two should bring about; between one system of such relations and the possibility of others.

That which such ever sought-for poetics, "poetry" or, as Michel Rémy would have it, "poetic", consists in, might thus very well indeed be described as "an unrelenting epidermic search for its own essence, for a prophetic quality, religious in the widest sense of the world, a quest for synthesis that would mean spiritual revolution". Now a particularly curious word here is "essence" - a noun which could seem to denote some singular, distinct and intrinsic or definitive "quality" of the desired "poetic". I would submit, though, that the French critic is using the word in the sense David Gascoyne (or rather my David Gascoyne) would give to it. In order to understand what sort of "essence" interests the poet one must consult The Sun at Midnight. In one of its first aphorisms, the piece entitled "Idea for an Anthologist", Gascoyne envisions "[t]he ideal aphorism" which "communicates essential insight [my italics]" [33, p. 5] and which, he speculates, should best be thought of as "a special kind of prose-poetry" - since "[p]oetry", whether aphoristic or not, "is among other things the concentration of imaginative essences; philosophy is the concentration of wisdom". It appears implied here that the English poet's endeavour involves freeing "[p]oetry" (and, one might infer, the "poetic" as well) from the authority of any single definition or any fixed combination of definitions - whose possible claims to self-sufficiency are preemptively dismissed ("among other things"); accordingly, in "Idea for an Anthologist" as well as in other Sun at Midnight aphorisms "[p]oetry" is presented in terms of its relation not so much to (its) "essence" as to "essences." The difference seems instructive.

Firstly, it follows that just as there can be no single definition of that which Gascoyne sees as "[p]oetry", there is no single underlying material or element whose transformations would be its domain; what is stressed instead is the plural, disseminative character of what "[p]oetry" works upon (and with). Secondly, one could argue that the phrase "concentration of imaginative 
essences" is ambiguous: it could be taken to mean an activity of extracting "essences", but one might read it as a process of ever greater "concentration" of such "essences", too - a process in which a given "essence" is transformed and clarified. The second reading in particular would seem to cast doubt on the possibility of interpreting any such "essence" as a Ding an sich, or a given phenomenon's final "nature" or quintessence - the latter would be irreducible and unchangeable by definition. Besides, those "essences" here are said to be "imaginative" - that is, ingenious, visionary and created by or indicative of lively imagination, to be sure, but also, as one could easily want to construe it, made-up, given to indulge in the imaginary, the fictional or the fanciful - or in make-believe. And since it is "[p]oetry" that Gascoyne is seeking to characterize here, such a reading is hardly inappropriate - nor one the poet himself would reject. Gascoyne writes that a poem, no matter how revelatory or transformative it is or urgently must be, cannot yet avoid being "an ingeniously and competently made verbal object" [13, p. 45] - an artifact and, ultimately, a linguistic concoction: "However impossible it may be to define poetry adequately, and however mysterious the nature of a poem, we can say with some certainty that the original etymologically derived meaning of a poem was approximately a making, a vessel made of words". Regardless of what such an apocalyptic "verbal object" may seek to reveal - regardless of what can be seen through the walls of the "vessel made of words" or what will pour from it - it still is an artificial apocalypse, fictional and made-up.

What both interpretations discussed above and their vocabulary of "essences", "vessel[s]" and such laboratory operations as "concentration" once more point towards that which is not merely one of the themes, but more importantly one of the basic affinities, of "[p]oetry" as Gascoyne would understand it - towards alchemy, that is. "A Kind of Declaration" as well as other Sun at Midnight fragments devoted to an investigation of the metaphor of "essences" provide further hints of the rapport, shedding some much needed light on what the poet sees as the workings of alchemy. "[O]ne of poetry's many possible definitions", Gascoyne observes [22, p. 160], stressing once more such "poetry's" inevitably elusive and ambiguous nature, is "that it is the distillation of essences" - and, most aptly, in the collection of aphorisms he characterizes "Poetry" as "spiritual naming and making of essences" [33, p. 38], expressing a view that differs slightly both from the one put forward in the imaginary interview and from his take on the issue formulated in the previously discussed Sun at Midnight pieces. Once more presented here as dealing with plural "essences", the procedures of that "poetry" - just as the ones of traditional alchemy - are thus said to extend beyond "concentration", embracing "distillation" or sublimation and "making" as well. The latter obviously recalls Gascoyne's cautious attempt to trace the etymology of the word "poem" to "a making, a vessel made of words", implying both that a poem is "a vessel" in which "essences" interrelate, combine and transform, and that a poem itself might just as accurately be seen as an "essence," an interaction of "essences" in its own right, and an "essential" process of their, as well as its own, "making". But, just as importantly, the activity of "making" evoked here - especially here, in the context of "naming", which Gascoyne appears to regard as an instance of "[c]reatio ex nihilo" [12, p. 255], as giving conventional reality to that which ultimately is not, to "The Nihil" [33, p. 36], "The Void" [12, p. 255] or the horizonless, endlessly open space provides also further evidence to my suggestion that what the English poet refers to as "essences" are nowhere near things in themselves, nor could be really thought of as the basic substance: what already is cannot be created; what is ultimately real could suffer no change. If Gascoyne insists on making use of the confusing word, he may be doing so in the hope of subverting the Platonic or Aristotelian notions of a transcendent "essence" and replacing them with a vision of changing, 
artificial "essences," made-up "natures" of making; and it would hardly be wrong to regard the "Great Work" of his "poetry" as consisting in the transmutation of (the notion of) the clotted, stale and thus "poisonous" [33, p. 45] "essence" into an alchemical drama of flowing "essences".

Accordingly, one ought to imagine "essences" whose changes Gascoyne's "poetic" deals with as active ingredients of the process, intermingling and ceaselessly transforming ("making") extractions that seek to effect change; as "influences" - to recall one of Michel Rémy's keywords which comprise and co-create the CEuvre no less than the "influences" that the alchemical process exerts on what it works with. While in the end such "essences" must transcend all particular elemental constitutions, throughout The Sun at Midnight Gascoyne tends to associate them either with fluids or, more obviously so - perhaps in order to stress their volatile and changing "nature" as well as their "potency" to inspire and influence - with air and airborne scents. One of the collection's aphorisms discusses, again against the implicit alchemical background, the myth of Odin drinking from "[t]he magic spring which conferred on those who tasted it the powers of poetry and prophecy" [33, p. 44] as it is told in the passage "[f]rom the Eddas" cited from the title-page of Tom Blackburn's "The Price of an Eye". "The date is to-day: 10.V.69" too plays upon the first of the two connections: in the aphorism, the image of the personal "Athanor" [33, p. 25] is projected onto the collective alchemy of the history of the Occident, and reinvented - in continuity with both one of the traditional representations of "Athanor" (Burckhardt tells us that athanor is "a small tower surmounted by a dome" [8, p. 161] containing the glass vessel (usually egg-shaped) which lies in a sand-bath or ash-pit situated immediately above the fire. All of this," the scholar continues, "has both a literal and a symbolical meaning, for although it is certain that the ovens of this shape were in fact used for all sorts of chemical and metallurgical operations, the real athanor - as far as the 'Great Work' was concerned - was none other than the human body, and thus also a simplified image of the cosmos") and Gascoyne's view of "Man" as "not the cause but the vessel of wrath, the diseased victim and the intended instrument of this temporarily disastrous working through process [my italics]" [33, p. 9] - as that of "the historic crucible" [33, p. 31], where the transpersonal "essences" are mixed and transformed. And, with regard to the other pairing, in "Nietzsche: the last great Unholy Fool", the German philosopher is said to have become "poisoned by Satanic influence and made giddy by an overwhelming hubris" [33, p. 37] - as if it was his inhaling of the fumes of the baleful "influence" that made him "giddy"; not quite inappropriately in the context of the existential thinker, the image Gascoyne's phrasing evokes is a return to his metaphor of "[t]hought's odour" [see also [26]). Throughout The Sun at Midnight, moreover, the notion of "essences" is apparently interchangeable with the one of "tincture" [33, p. 39]: in "News from Eden", for instance, a "sublime though divinely poisonous tincture" is said to be that "which produces the final gold of the philosophers" [33, p. 39]. The word, tracing the association of "essences" with fluids further ("tincture" meaning a medicine consisting of an extract in an alcohol solution), highlights above all their "essentially" pharmacological character; secondly, it implies once more that the "nature" of an "essence" lies in its influence, its "potency" - i.e., in its capacity to disperse itself, become absorbed and change that which it comes into contact with ("tincture" as a pigment, a colouring or dyeing substance); thirdly, it re-emphasises the radical elusiveness, the ephemerality and the fickle, changeful disposition of "essences", which, we seem to be given to understand, are unstable and volatile ("tincture" in the sense of a vestige or a trace: an indication of a presence-no-more, a failed presence or a haunted absence).

Now to return again to Michel Rémy's description of Gascoyne's "poetic": if it is "an unrelenting epidermic search for its own essence", its self-seeking endeavour will be self-defeating also 
because the "poetic" in question searches "for its own spirituality by a combination of influences" - striving not so much to unveil as to concoct (or perhaps reveal through "making") both its modi operandi and "its own essence" not only in, but also from, its ceaseless encounters, from what is created in the course of the experiments that are meant to delimit or recreate its environments, lineages, and its relations to the latter. The "essence" of the "poetic" is thus discovered in and as its other, and promptly rediscovered as another or another amalgamation of others, indefinitely; trying to locate its centre through and on the endlessly receding periphery, the "poetic" is forced in this way to differ from itself as much as its other differs from it and from itself - and, interminably, it cannot but enact the "essential" lack of itself and its open-endedness just as it cannot fail to transcend itself. Accordingly, that which must "mean spiritual revolution" is the sought "synthesis" no less than the very "quest for synthesis", if the two could be understood as ultimately discrete at all: the "spiritual revolution" spoken of here leads to, embodies or dramatizes the "synthesis" as much as it $i s$ that "synthesis", the "synthesis" that always means another "spiritual revolution" and must always differ from itself as much as from that which it seeks to transcend. If there is any "essence" to be discerned here, it has to be a self-transcending one.

What Gascoyne himself said on poetry in the course of the cited Stand interview seems to shed still more light on Rémy's felicitous phrasing. "To me", the poet tells Lucien Jenkins [16, p. 53], "poetry is a mysterious gift of putting words together in a certain way. Poetry is like a substance, the words stick together as though they were magnetized to each other". This "essence" or "substance", then, images poetry's character as that which, being the "gift" of relating - both that "mysterious" something that makes "putting words together" possible and the very activity of composition, of making "words stick" - is also the result of such an activity, a series, a pattern or a compound of "words" put "together in a certain way". A complex, plural process, the "poetry" talked about here is that which is changed even as it changes; that whose influence is always reciprocal; that which, negotiating between diverse states of aggregation, is itself a narration of differing fluidities. And it is not abstract, being instead "like a substance": tangible, sensuously material and malleable - malleable as far the relations between the magnetic "words" go, but also with regard to the equally adhesive "influences" Rémy speaks of, both being the stuff the "poetry" which Gascoyne strives to imagine is made on, the stuff whose life evolves in the metre of endless, ever-new and unpredictable alteration. In a lecture the English poet gave in the December of 1936 Gascoyne steals one Dr Schmallhausen's phrase - "[1]ife newly re-discovered" [14, p. 28] - and interprets it in order to explain what "poetry" all in all boils down to: "life perpetually rediscovered, re-created anew - that is the very essence of poetry, as I conceive it". What we are told is that "the very essence of poetry" is either paradoxical or unthinkable and absurd: "essentially" it amounts to the lack of any ultimately identifiable intrinsic features, the lack of any "essence" that could be apprehended as this or that. That "very essence of poetry" is thus the lack of any findable "essence", the lack of its very self: a spiralling loop of failed "essence" or "essences" and their failed lack; a flagrant, endless self-contradiction. Gascoyne evidently has good reasons to point out that "perhaps poetry is in the mystery" [29, p. 310], never wholly present nor the same, ever beyond itself and, being ever in that which is unknown ("the mystery"), ever unknown - or to describe "poetry" as a genuinely "mysterious gift", a "gift" that is its own constant erasure no less than a subversion of what it encounters.

It is scarcely surprising, then, that Michel Rémy takes such care to point out the "unrelenting" character of the self-seeking "poetic" Gascoyne's "poetry" entails - "unrelenting", which is to say both ceaseless and unappeasable - and to stress that its "search" is turned inwards in such 
a way that each moment of that journey within, "epidermic" and visceral, localizes the "inside" ever elsewhere, ever further "inside", endlessly multiplying the sought "essence" and revealing the process of its "unrelenting" differing from itself. One would not be wrong to observe at this point that if it is "a poetic" that seeks "its own spirituality" as much as its own "essence", it is "a poetic" that seeks itself just the same. Now just as the emphasis on the "epidermic" and "gut-grabbing" disposition of such "poetic", Rémy's depiction of it as ceaseless exploring and searching ("sought", "unrelenting [...] search", "quest") cannot fail to bring to mind - and, since it is said to have "sought for its own spirituality by a combination of influences", could hardly fail to suggest tracing that "poetic" to - Benjamin Fondane's existential poetics; besides, Rémy observes that it was the Romanian poet and philosopher's "book on Rimbaud [Rimbaud le voyou et l'expérience poétique]" [43, p. 125] that, alongside "the poetry of Pierre Jean Jouve" and "of German romantics", "introduced" the English poet "to the existentialism [sic] of Leon Chestov", helping in this way Gascoyne "to reorientate himself towards" the "poetic" that I have been discussing. "He was a searcher", says Gascoyne of Benjamin Fondane [17, p. 22], "it is [difficult] to anybody to be a searcher and not to have fixed ideas, but to always be trying things out, and wondering and asking as profound questions as possible. I mean it's bound to be a lonely position. You can discuss things with people and not agree with them, without quarrelling with them. Surrealists couldn't, but other people could".

While these words help better understand what it means for Gascoyne to be an authentic "existential thinker", they are just as relevant to any discussion of Fondane's, or Gascoyne's, "poetic" as well - if the latter could survive any separation from the project of existential philosophy, that is; as has been suggested, the English poet sees the two as inextricably interrelated at the very least in his own and Benjamin Fondane's case: he refers to the latter as a "poet and philosopher" [23, p. 82] but also, much more tellingly, as a "philosopher-poet" $[25$, p. 52] - and it is this view that underlines the portrait of Fondane Gascoyne sketches in the preface to Le Mal des fantomes, the text which reinvents both "the poet Benjamin Fondane" [28, p. 178] and Fondane "the existentialist philosopher" [28, p. 181] as "Fondane the Gadfly, the spokesperson of the persecuted and the prisoners, the Seer, perhaps above all, the Rebel" [28, p. 178], not only half-obliterating the distinction between "poetry" and existential thought, but eventually removing from Fondane's writings their traditional horizons altogether. In the preface, writing about Fondane "as a character in the mythology of the modern poets" [28, p. 179], Gascoyne declares that the Romanian poet "obviously [...] cannot escape from the family of the 'damned'; at bottom, that is tantamount to saying that he paid the price for his double gift of prophetic clairvoyance and Orphic speech, while accepting a wound and a curse" [28, p. 179-180]. What Gascoyne sees as the very spirit of Fondane-the-poet's vocation is portrayed here in words that unmistakably recall the phrase he used some thirty years earlier, in 1949, to outline the tortured role Shestov-the-philosopher found himself playing "his whole life long" - the role of "a Voice Crying in the Wilderness" [23, p. 80].

Following Fondane into that "[w]ilderness", where there is no one to follow and where one must be "lonely" and lost beyond all routes, signposts or enduring tracks, Gascoyne embraces the "poetic" that not acknowledges the chaos it explores, but also admits its inevitably being a part of the latter. Accordingly, his "poetic" is given to ask "as profound questions as possible", insisting neither on holding to or getting any answers, nor even on the ultimate relevance of such "questions"; it hesitates to identify itself, refuses to limit its disposition, affiliations or scope, and seems somewhat reluctant to define the exact nature of its ultimate goal ("to be a searcher" is "not 
to have fixed ideas, but to always be trying things out [my italics]"); and, since such "poetic" has no "fixed ideas" or stances it would be willing to identify as its "own", while it does obviously rely on differing tension, it also allows for the kind of difference that need not entail conflict nor hierarchisation ("You can discuss things with people and not agree with them, without quarrelling with them"). Actually, one would not be in the wrong to argue that what "a poetic" of that kind seeks is to discover a way of inhabiting and living with that chaotic "[w]ilderness", welcoming its "mystery" and letting itself be shaped by it much more than attempting to give it some shape: "I am not a director of consciousness, but a consciousness in search of a direction", writes Benjamin Fondane in the letter he sent to the younger poet in July 1937 [25, p. 54]. As the context evinces, with that sentence Fondane effectively renounces his authority, subverting what could have been misconstrued as his being a mentor to Gascoyne - and he tries to make the English poet aware that it is not so much that he is quitting right now as that he has never quite accepted any such role in the first place; the supposed hierarchy of their relationship is in this way brought into question, and the affinity between the two poets becomes, as Gascoyne was to entitle his brief memoir of their friendship, a series of "rencontres" - lucky "meetings" whose spirit appears to have been that of exchange, co-influence and sharing. But the words cited from Fondane's letter make it also clear that any "poetic" that could be convincingly traced to the Romanian thinker's trademark self-seeking and self-questioning "stance" must relinquish all desire to tame, stabilize or imprint itself on the chaos it espouses: instead of seeking to become "a director of consciousness", it must acknowledge itself to be a "consciousness" always "in search of a direction" - at least as receptive as it is active; an integral part of what it deals with, and not a transcendent catalyst; a centreless "consciousness" that is simultaneously looking for a centre and for a final deliverance from all centredness.

The stark open-ended tension at the heart of such "poetry" is by no means purely destructive, though - nor does its possible interminability mean it is "essentially" useless. If the "poetry" Gascoyne envisages is "a mysterious gift" and is always "in the mystery" that it must differ from, its "mystery" will also be a self-transcending one, the "mystery" of (its own) healing transformations - and one co-creative of life, too. Recalling how he was "bewitched by the voices of popular singers: Piaf, certainly, but also Marianne Oswald, Brassens, Ferré, Catherine Sauvage" [28, p. 175], Gascoyne concedes that their uncanny influence can hardly be seen as anything but "a matter of spell, something inexplicable". Observing a few lines later that " $[t]$ here are a series of words or phrases which can haunt us, as is the case with the 'haunting refrain' to which I have already alluded, something that carries us away and moves us to a degree which cannot be rationally explained" [28, p. 176], whether it is "poetry" or music, Gascoyne seems to an extent to reiterate his previously expressed view - but the focus is different this time, expanding on the theme of "poetry" being "a matter of spell" more than on its being "inexplicable". The modalities of "poetry" underscored here are these of displacement, release and transcendence ("something that carries us away"); of magical, elusive transformations ("moves us to a degree which cannot be rationally explained"); and of a transmutative encounter with the uncanny ("words or phrases which haunt us [my italics]"). The scope and the precise nature of (as well as the real reason behind the very occurrence of) the inspiriting metamorphoses such "poetry" enacts are again said to be ultimately "inexplicable" - but it is the influence of that final mysteriousness, its "potency" and capacity to act that are brought into focus this time. "Transform the world", Marx said; "Change life", Rimbaud said. These two watchwords are one for us," asserts Breton [7, p. 241]; and what Gascoyne might be seen as doing here is framing the fundamental "mystery" of that which he believes constitutes genuine "poetry" in the context of Breton's surrealist credo. 
Now although Michel Rémy links the emergence of Gascoyne's alchemical "poetic" - the word which the scholar draws his readers' attention to can of course be used to refer both to the theory of writing poetry and to the latter's practice, and for the English poet (as much as for those surrealists who succeeded in staying loyal to Breton's constantly reformulated doctrines) all genuinely useful, which is to say existentially relevant and, potentially at least, transformative, theory of "poetry" must be "poetry", too - to his "grow[ing] dissatisfied with Surrealist activity" [42, p. 21], neither the French critic's nor Levi's construals of that "poetic" as an "alchemy" of "influences" by any means undermine my reading of David Gascoyne's "poetic" theory as fundamentally surrealist. As I have been striving to show, the "poetic" which Gascoyne is "able to reorientate himself towards" once the obscure "fracture" Rémy refers to has happened, the "poetic," that is, which searches for "its own spirituality", for "its" means of liberation and "its own" realized liberatory potential in and through (a ceaselessly varying "combination of") others - what it seeks for "by a combination of influences," Rémy insists, is precisely "its own spirituality [my italics]" - is not only an unavoidably interminable search for what could never be grasped but also an endless, multi-layered and continuously altering self-contradiction, a living "process" of self-rupturing or self-transcending; and being such, it appears to exemplify very well indeed what the French critic suggests to be the defining disposition of all authentically surrealist writing [44]. "British surrealist writing" [44, p. 39] in particular, Rémy explains, "confronts us with our double and deprives us of our univocity" - just like the poems that make up Gascoyne's Man's Life is this Meat, those "eighteen similar texts which offer no solution whatever to the liquidation of meaning and accumulate instances of perfect deconstruction" [44, p. 35], in this way "becom[ing] a place for transformation" - the texts" "transformation" as much as their readers', that is: "As a result, the subject is deprived of its identity and nothing can be 'etched upon the eyes' quick web', not only the subject in the text, but also the reader since both are situated between their imminent qualification and their ensuing disqualification" [44, p. 35] - and since in the act of reading "the text" and its "reader" become interdependent: "Words take $u s$ beyond the surface of things, making us transmute them on the way [my italics]" [44, p. 38]. Any "journey to the centre of the text" [44, p. 36] will thus be, in all surrealist writing worthy of its name, "a journey through meaning and making of meaning" [44, p. 37] - the "journey" to "a centre which can be reached only in the movement which carries us towards it. And of course, as soon as we reach it movement vanishes and so does the core we were working towards [...]. What we must do then" [44, p. 36], the critic suggests, "is settle in a world of perpetual change; indeed, what is at stake is our relationship with what is living, a preoccupation central to surrealism. All constructions must be incomplete", as not only surrealist poems and prose but also films prove especially well (Rémy is thinking here of Len Lye's films in particular - which exemplify, the critic argues, the surrealist "obsession with what is unfinished and cannot be finished", the "obsession" that so visibly marks all of Gascoyne's "poetic" projects), and "what matters is to understand that it is impossible to impose any order on "reality" - the insight which surrealist writing will often evoke in terms of "a violent contrast" between "its own syntactical logic and the totally illogical quality of what it conveys"; it is "[a]s a result of this internecine fight between the signifier and the signified" that "any notion of structure and order soon proves to be inadequate". The existential realization which surrealist texts seem to promise (and surrealists, Gascoyne included, hope to effect) would therefore be twofold. Firstly, through an encounter with such writing one may become aware of the chaos and impermanence of "things" - which, we find out, are not really things: what "is revealed" [44, p. 37] in the course of such meetings is also the unreality of "[t]he object in question" or, in other words, "the impos- 
sibility of giving it any kind of identity. Its presence can only be grasped by proxy, so to speak, through the suggested possibilities and impossibilities." Secondly, the moment "[ $t]$ he interior and exterior fuse" [44, p. 38], Rémy explains in another wonderfully chosen phrase, "space is disrupted and so is time, and we pass from historical time and precise geography to timelessness and absolute space" - and, while thus transcending "time" and "space" for a (timeless) instant, we might recognize "the mind's essential nomadism" [44, p. 39]; we could, that is to say, discover that "mind" which is aware "non-contradictorily" of "the collective and the individual, the preterit of the photography and the future of the word, the historical and the timeless, the body and the landscape, memory and desire" [44, p. 39] - and thus realize the surréel.

Another brilliant essay most pertinent here is "The Transparent Mirror" - an article written by Brian Merrikin-Hill, a fellow poet and as admiring a critic of David Gascoyne's ceuvre as Rémy is. Seeking to explain "why the first book on Gascoyne is in French and why the greatness and importance of David Gascoyne have been forgotten in England" [38, p. 275], Merrikin-Hill draws further convincing parallels between what he sees as the nature of Gascoyne's "poetic" in general, and of its "alchemy" of "influences" in particular, on the one hand, and, on the other hand, the genuine surrealist spirit as defined by Breton, that arch-surrealist - and the critic's useful exposition of Gascoyne's "poetry" (in the sense the English poet would give to the word) is not only firmly grounded in but also happens to shed important light on that reading of the presently discussed "poetic" which Rémy puts forward. Having spoken of (and emphasised) "the enormous importance of surrealism" [38, p. 274] with regard to the way which Gascoyne finds himself practicing "poetry" in, Merrikin-Hill observes that the kind of speculation which the English poet's writing leads, or, perhaps, lures its reader into and which his philosophy of poetry above all involves "is far from modern English discussion of poetry" [38, p. 275]. The "English" critics, Merrikin-Hill argues, "discuss the surfaces and trappings of poetry, not its substance" (in, it would appear, the alchemical sense of the word) - and, as a result, "David Gascoyne as 'The Transparent Mirror"" cannot but be "too serious a poet, too truly poetic a poet for journalism to regard seriously", the critic bitterly adds, the word "journalism" having here a distinctly unpleasant (and accusatory) tone; in fact, that which Gascoyne's "poetry" actually consists in may very well be bound to remain literally missed out "in England" - for the majority of the "English" critics, we are suggested, will utterly fail to discern, let alone understand it:

"It is appropriate to quote from Breton's Third Surrealist Manifesto [Prolegomènes à une troisième manifeste du surréalisme ou non]: "at the end of twenty years, I see myself obliged, as in the time of my youth, to pronounce myself against all conformism, and in saying this to take aim at a certain too conformist surrealism as well. Too many pictures, especially, deck themselves out in the world, that have cost nothing to the numberless followers of Chirico, of Picasso, of Ernst, of Masson, of Miro, of Tanguy - tomorrow it will be of Matta - having cost nothing to those who do not know that there is no great enterprise in art that is not undertaken at peril of one's life, and the road to follow is not, on the evidence, that which safeguards and guard-rails, and that each artist must undertake alone the pursuit of the Golden Fleece." David Gascoyne undertook the pursuit of the Golden Fleece at the peril of his life and Michel Rémy has retrospectively charted the voyage. Gascoyne was influenced not only by Chestov, Berdyaev, Kierkegaard, Nietzsche and Hölderlin, but by Buber, Boehme and Eckhart - yet his work is not syncretist or an amalgam; it is with the knowledge that these also travelled in the unmapped that he took his own journey. Michel Rémy, meeting the problem of influences, says 
that the solution of the dilemma is to see the "influences" as integrant parts of the writing of the text, which proceeds not in a linear but a tabular manner and is a lateral communication, always free and open, not a plumbing of a known depth. "The poet is he [sic] who does not know; he is not the reflection of knowledge he has learned nor the place for its repetition; he alone possesses the measure of his knowledge: far from being the 'honnête homme' of the classicists, for whom there was an ideal knowledge, he is the only origin of the extensibility of his knowledge" [38, p. 276].

If Merrikin-Hill hits the nail on the head here with his terse résumé of Rémy's "solution" of "the problem of influences" in the English poet's writings - the "solution" which, as should have become clear by now, deeply informs my approach to both Gascoyne's writings and the texts they are influenced by (or resonate with) and which consists in "see[ing] the 'influences' as integrant parts of the writing of the text, which proceeds not in a linear but a tabular manner and is a lateral communication, always free and open, not a plumbing of a known depth" - no less than with his characterization of Gascoyne's "poetry" as " "the pursuit of the Golden Fleece" undertaken "at the peril of his life", the critic's words also happen to perfectly coincide with, and could possibly be seen as providing some evidence to support, the poet's own conviction that what he understands by the word "poetry" is a concept mostly unrecognized in Anglophone countries. "More and more, I feel the existence of a great gap between their generation's concept of poetry and my own", comments Gascoyne in the journal entry dated August 8, 1938 $[12$, p. 69] on the "three volumes of new poetry from Fabers: Auden, Spender and MacNeice" he has just "received by post" - and "confesses the need to explain in writing all that this gap means". As Gascoyne conceives of it, "poetry" does not lie in, let alone boil down to, one's "slick technique" or "mastery over words", however great it might be - and, although it may very well demand utmost "sincerity" on the poet's part as well as her or his "real passion", neither of the two possible requisites will ultimately be its secret, "poetry" no more being an expression of the poet's personality, of her or his emotions, ideas or intuitions, than it could ever be reduced to a mere craft or trade. "Poetry", we are told [12, p. 170],

"[...] is not verse, it is not rhetoric, it is not an epigrammatic way of saying something that can be stated in prose, nor is it argument or reportage. In England, the whole question needs to be cleared up and restated. What I call poetry, is not understood in England, but I believe it to be something of far greater value than what is at present understood there. The tradition of modern English poetry is really something quite different from the tradition of Hölderlin, Rimbaud, Rilke, Lorca, Jouve. - I belong to Europe before I belong to England. The values I believe in are European values and not English ones. Indeed, at least insofar as "poetry" is concerned his "values" strike him as being so very "different" from what he regards as those of the "present"-day "English" that Gascoyne will often choose the French word over the English one - and speak of "poésie" [12, p. 206] instead of "poetry". In the journal entry dated November 3, 1938 - the important entry in which he recalls his recent meeting with Tristan Tzara and which brings into clearer view the surrealist origins of Gascoyne's "poetic" - the poet asserts that "the fundamental distinction, which [Tzara] himself had made, between poésie - moyen d'expression and poésie - activité d'esprit [...] corresponds roughly to the distinction between the English conception of poetry and the French." And Gascoyne's enthusiasm for the "distinction" the Romanian surrealist postulates is anything but short-lived; the poet will still endorse the "fundamental" double parallel more than fifty years later, as evinced by his 1992 Stand interview - in whose course he also sheds a bit more light on what he understands "poetry" (or perhaps rather "poésie") to consist in: "Poésie cannot be translated by the 
English word poetry. Since the middle of the nineteenth century there is the mantic idea of poetry. There is a poem by Victor Hugo called 'Ce que dit le bouche d'ombre', the mouth of shadow; the poet is a mask, through whom words from beyond come. Baudelaire is an example and Rimbaud and Mallarmé" [16, p. 48].

It should be noted at that point that while Gascoyne does explicitly reject the notion that "poetry" is a purely literary phenomenon, or even one which necessarily involves writing - he insists that "[p]oetry is by no means restricted to the printed page" [14, p. 31], and the fragmentary expositions of "poetry" which can be found in the English poet's journal entries, lectures and interviews I briefly discussed above clearly indicate that he must have to a great extent agreed with the much-publicised statement Breton made in 1923: "La poésie? Elle n'est pas où l'on croit. Elle existe en dehors des mots, du style, etc. C'est pourquoi je suis ravi de lire des livres très mal écrits. Seul tout le système des émotions est inaliénable. Je ne puis donc reconnaître aucune valeur à aucun mode d'expression. L'histoire littéraire, c'est le fruit d'une transposition des plus vulgaires" [2] - and while Gascoyne does assert that "[p]oetry is not verse, it is not rhetoric, it is not an epigrammatic way of saying something that can be stated in prose, nor is it argument or reportage", at the same time he will never deny that any of these could become, when properly used, a "vehicle" for the workings of "poetry" (or "poésie", to employ what could be the more appropriate word here). It is not, however, that "poetry" simply takes on the guise of or manifests as literature when the poet desires so: the relationship between the poetic and the literary as seen by Gascoyne appears to be a much more complicated and troubling issue.

In the entry dated July 3, 1939 the English poet, discussing the ambiguous bond between "poetry" and literature, envisions that which gives him his poetic identity as an alien and monstrous Doppelgänger he is the host to - an image that would appear to owe as much to Breton as it does to Georges Bataille or Antonin Artaud: "I am dominated by a voracious imagination, a turbulent creature which inhabits me; whose continual demand, allowing me no rest, is to be fed. The writing of poetry corresponds only to the digestive process of this monster" [12, p. 250]. The terrifyingly inhuman life of the in-dwelling monstrosity feels to its host physically, intimately present - and intimately other; but, as the phrase "writing of poetry" seems to hint, it is probably just as other to itself, just as haunted and as uncannily self-divided: "The imagination is possessed by a force which is not only hunger. It suffers also from a sort of continual claustrophobia, a will to objectivization, a desire to break bounds and thus change the world (sadism). If it were possible, I would sooner give expression to this force in my life than in my work". Now that which Gascoyne is referring to here as "voracious imagination", while not entirely synonymous with "poetry," appears to be an aspect, a modality or a dimension of the "genuine spiritual activity" which "poetry" incarnates - and the lust consuming and driving the grotesque "creature" is its "continual demand" for new life, new form, for the freedom from all form and formlessness alike, for that which is not and for what could never be. And that beastly and domineering Doppelgänger is in its turn "possessed" as well - by a strange, multiform (or polymorphous) "force" which transcends mere "hunger," combining "claustrophobia", a "will to objectivization" and a sadistic "desire": a thirsting process whose complexity makes it difficult to comprehend or respond to, and which appears to be so intense that one could well wonder whether "writing of poetry", which "corresponds only to the digestive process of this monster", could ever slake it. Gascoyne's journal self certainly feels that "the digestive process of this monster" is uncannily misplaced - that he cannot really fill the lack whose sense the "turbulent creature" is tormented by with words or images: "If it were possible, I would sooner give expression to this force in my life than in my work". We are given to under- 
stand, then, that if we wanted to be able to more properly feed the "voracious imagination", and in this way heal our inescapable relationship with it or at least make it less "turbulent" and less anguished, we would have to pursue a sort of "poetry" that entails neither literature nor art. In the 1930s and 1940s Gascoyne appears inclined to believe that for him liberating "poetry" from the literary and the artistic is in the end unfeasible - even though that is precisely what ought to be done. In the entry dated April 11, 1937 the poet revisits Lautréamont's famous pensée, placing it in the context of what appears to be the programme of a surrealist revolt formulated in the idiom of a Lawrentian apocalypse: "Artist: poet. Poet, artist: someone with a special sense of existence. 'La poésie doit être faite par tous. Non par un'. Everyone should be a poet in that everyone should have a (special) sense of existence. When everyone living is fully alive, the functions of the professional artist as he is known today will be extinct" [12, p. 81].

Both for Gascoyne and the French surrealists, that urgent desire to release the genuinely poetic from the restrictions of the literary obviously has its roots in the Dada experience: "Most of those who actively participated in Dada were either writers or painters; which amounted to saying that nothing could be calculated to arouse their disgusted derision more effectively than literature and art", explains Gascoyne [19, p. 166]. "For the contributors to this review, 'literature' was no more than a term of contemptuous ridicule; it was adopted as a label out of sort of wry self-depreciation" [19, p. 167] which "was due to it being only as it were shamefacedly, as a result of an absurd, all-too-human feebleness of mind, that these writers wrote at all" [19, p. 167-168]. The "poésie" Breton spoke of in the 1923 interview cited above was to be made in the sole service of "life" just as Dada was, even if sometimes rather unwittingly ("It seems scarcely credible that anyone could be at the same time active and at rest, that he should be devoted, yet maintain an attitude of rejection; and yet it is in this very anomaly that life itself consists, naive, obvious life, with its indifference toward happiness and death, joy and misery. The Dadaist is naive. The thing he is after is obvious, undifferentiated, unintellectual life" [35, p. 43]) - even, one could add, if Dada at times bitterly protested the very "life" it sought to protect. Breton recalls that Jacques-Emile Blanche already in 1919 wrote that "Dada will survive only by ceasing to exist" $[3$, p. 56], and it would be difficult to overestimate the importance of the paradoxical statement - which appears to throw into relief what is not only a crucial feature of the Dada movement but one that seems very pertinent to the discussion of the relationship between "poetry" and literature in Gascoyne's project. One could argue here that Dada's "ceasing to exist" and its subsequent rebirth (or rebirths) are simply consequences of its taking into account and responding to its own failures as much as to the crisis it is reacting against - but it would be hardly incorrect either to point out that Blanche's phrase might just as well be read as saying that while Dada seeks to secure its persistence in and through spreading chaos, the disorder it causes will be internal as well: Dada goes on by ceaselessly rupturing and disrupting Dada, and, should the need occur (should the "life" which Dada has sworn its allegiance to require it, that is) it will gladly contradict itself to the point of its apparently final self-erasure and enact its own demise - which will also be, or rather actually was, its rebirth as surrealism. Or perhaps Dada would be better thought of as having always been but a juvenile, or only partially revealed, face of the surrealist venture - or, another possibility Gascoyne puts forward, that which gave birth to the latter movement, the child that in no time consumed its mother wholly: "Already, in the midst of the tumult of Dada, the seeds of surrealism was growing. As we have seen, they were perhaps the least Dada elements of the movement (which wasn't a movement), the nonconforming dadaists, who became surrealists. 
So I think we can say that the development from dadaism to surrealism was dialectical. Dada: negation. Surrealism: negation of negation; a new affirmation, that is" [31, p. 45].

Both Dada and surrealism share the spirit of "negation", then, which was first starkly embodied by Dada - and the raised to another degree and reborn as surrealism, it being "negation of negation" (even though what such double "negation" amounts to is "a new affirmation") - and whatever their exact historical relationship might have been, once Dada has "cease[d] to exist", it does not disappear but instead immediately starts to haunt surrealism: among the surrealists avant la lettre Breton cryptically mentions Jacques Vaché, that ultimate - and, as it happens, avant la lettre as well - dadaist of all times: "Vaché is Surrealist in me" [4, p. 27]. How could one ever hope to separate the Dada adventure from the surrealist endeavour?

The brief detour into the question of how Dada is actually related to surrealism is not irrelevant - it provides me with an imperfect but useful analogy. One could argue that David Gascoyne's poetic project features a not dissimilar relationship between the processes of "poetry" and "[t] he writing of poetry", or "poetry" and literature: in spite of the urge to liberate "poetry" from the literary which the English poet felt throughout the 1930s and 1940s (if not later as well), he is aware only too well that his attempts at unshackled "poetry" are ceaselessly collapsing into "writing" - which Gascoyne is then frantically trying to make yield or release the poetic they hide. While the poet has little doubt with respect to what his priorities are - it is always "life" which "poetry" is supposed to serve, and it is invariably the poetic which he deems superior to the literary - throughout his liberatory endeavour "poetry" and " $[t]$ he writing of poetry" turn out to be inseparable and interdependent: they flow into one another, taking each other's place, form or attire; they substitute their other for themselves, reveal the other in themselves and themselves as their other, so that either of them can be glimpsed through no less than in and as the other. And while it is necessary to constantly check whether one's pursuit of "poetry" has not started to degrade into the exercise of "belles-lettres" in which few traces of the genuinely poetic can be found, it is equally indispensable to keep making sure that the "poetry" one is practicing does indeed still serve "life" - that it is still authentic, still truly subversive and has not been corrupted into becoming its antithetical twin, overtly or covertly formulaic, ultimately inoffensive to the life-stifling culture and entirely specious. The already cited journal entry dated July 3, 1939 appears to suggest that the threat of degeneration is always there - that one's being a poet unfortunately means one is also, as Gascoyne phrases it after George Barker, "a powet" [12, p. 250]; the challenge, then, would seem to be to notice when "poetry" is no longer accompanied by a sense of "pretentiousness" but has begun to appear unaffected and natural to the poet - and promptly interrupt its transformation into the hollow double that not only distorts and betrays "poetry" but, if allowed to exist, inevitably consumes it, and then takes it place.

It ought to be added that sometimes saving "poetry" from such a fate will require subverting the very notion of "poetry". In the introduction to Kenneth Patchen's Outlaw of the Lowest Planet, a volume he himself selected, Gascoyne quotes a fragment of Patchen's in which the American poet first points out that "poetry" is writing - and then appears to denounce the former in favour of the latter:

"It is an absolute mistake to ladle out stress like a cook measuring off the ingredients for a cake. We've got a country full of cake-baking poets now, one just as good and just as bad as the next. - Poetry is writing. Maybe what I am talking about is not poetry (the stuff the critics are yammering about)... I am a writer and I shall write. The term 'poet' is a convenience of the middle class. I declare myself a writer. I want the room to move about. Spare me from the pawings-over of the cake-bakers" [19, p. 168]. 
Being, as Gascoyne puts it, "the lone one-man Dada of contemporary America" [19, p. 166], Patchen is struggling here to free the genuinely poetic from its customary trappings, to rescue it from the institution of practicing "poetry" and of being a "poet" that, just like the culture which gave rise to it (i.e., the "society" [19, p. 67] which is "organised solely for purposes of competitive commerce, the exploitation of subject races and the destruction (whenever necessary, and then with as thorough an efficiency as possible) of landscapes, armies, cities and even civil populations", yet whose "official representatives" never speak of "the existence of these universally evident evils"), is at present irredeemably hollow and corrupt - the effort which leads him to reverse the positions Dada would ascribe to "poetry" and "writing": he excoriates what has come to be regarded as "poetry," the "poetry" in the sense of "the stuff the critics are yammering about", the "poetry" that in the end is nothing more than a "middle class" pastime - and speaks in favour of "writing" instead because, he appears to reason (alongside Gascoyne), "writing" is what his "poetry" cannot but involve in any case. And since he is a dadaist, Patchen may also very well be decrying "poetry" here due to his urgent need to break free from all attachment - from his grasping after all sorts of preconceived identities (e.g., that of the "poet"), notions (such as "poetry") and predilections - and escape into a more open space.

It ought to be patently clear by now that David Gascoyne's understanding of what actually constitutes "poetry" in no way is a conventionally accepted one - and that in order to study his "poetry" one needs to draw on the body of the English poet's texts in a way which will not be hampered by any map of conventional genre borders - nor, indeed, constrained by any ready-made notions of what is or is not "poetry". Accordingly, to explore Gascoyne's practice of "poésie" (which, as has been pointed out, encompasses his poetic theory as well) is to take a close look not only at the poems he wrote but also at his stories, novellas or novels; plays; aphorisms; film scenarios; essays and manifestos - as well as various fragments and more complete but still aborted or abandoned projects; marginalia, unedited pensées or notes no less than rejected outlines; philosophical sketches and reviews; journals, lectures, letters, interviews and other trivia, literary or, perhaps, otherwise. From the perspective which Gascoyne's "poetic" tests and explores, none of these "mode[s] d'expression", to recall here Breton's phrase, would be by definition more informative, more originary or more deserving of careful reading than any other since none of them is intrinsically more capable of becoming a "vessel" for the workings of "poésie" or "poetry" - of becoming a form and a space in and through which the drama of deliverance that I see as the essence of Gascoyne's écriture might unfold, that is to say - than others are; it should be borne in mind, too, that I am not speaking here solely of Gascoyne's writing - as Rémy and MerrikinHill note, one could neither isolate the English poet's "own" texts from those of his "influences" (or, for that matter, from the texts of the no less numerous "ghosts" [28, p. 179] which "haunt" him and his writing) nor assume that within the framework of the Grand Euvre of his "poetic" it is the writings which he himself authored that are primary, the other ones providing merely a context for the former; actually, it would hardly be inappropriate to see Gascoyne's écriture as the space of all such ghostly relationships, and not merely its centre.

\section{References}

1. Blackburn T. The Price of an Eye / Thomas Blackburn. - London : Longmans, 1961. - 170 p.

2. Breton A. Entretien avec Vitrac. Euvres complètes. [vol. I] / André Breton. - Paris : Gallimard, 1988-2008. - 1215 p.

3. Breton A. For Dada // The Lost Steps; [trans. M. Polizzotti] / André Breton. - Lincoln : University of Nebraska Press, 1996. - P. 51-56. 
4. Breton A. Manifesto of Surrealism // Manifestoes of Surrealism; [trans. R. Seaver and H. R. Lane] / André Breton. - Ann Arbor : University of Michigan Press, 1972. - P. 1-47.

5. Breton $\mathrm{A}$. Prolegomènes à une troisième manifeste du surréalisme ou non // Euvres complètes; [ed. P. Bernier et al, 4 vols.] / André Breton. - Paris : Gallimard, 1988-2008. - Vol. IV, - P. 5-15.

6. Breton A. Reply to a Survey // The Lost Steps; [trans. M. Polizzotti] / André Breton. - Lincoln : University of Nebraska Press, 1996. - P. 83-84.

7. Breton A. Speech to the Congress of Writers // Manifestoes of Surrealism; [trans. R. Seaver and H. R. Lane]. - Ann Arbor : University of Michigan Press, 1972. - P. 234-241.

8. Burckhardt T. Alchemy: Science of the Cosmos, Science of the Soul; [trans. W. Stoddart] / Titus Burckhardt. - Louisville : Fons Vitae, 1997. - 206 p.

9. Fondane B. Le Mal des fantômes / Benjamin Fondane. - Paris : Plasma, 1980. - 318 p.

10. Fondane B. Rimbaud le voyou et l'expérience poétique / Benjamin Fondane. - Paris : Complexe, 1990. $-296 \mathrm{p}$.

11. Gascoyne D. Anniversary Epistle to Allen // Best Minds: A Tribute to Allen Ginsberg; [ed. B. Morgan \& B. Rosenthal / David Gascoyne. - New York : Lospecchio Press, 1986. - P. 113- 115.

12. Gascoyne D. Collected Journals 1936-1942 / David Gascoyne. - London : Skoob Books, 1991. - 402 p.

13. Gascoyne D. Departures // Selected Prose 1934-1996; [ed. R. Scott] / David Gascoyne. - London : Enitharmon Press, 1998. - P. 44-46.

14. Gascoyne D. The Future of the Lyrical Imagination // Selected Prose 1934-1996; [ed. R. Scott] / David Gascoyne. - London : Enitharmon Press, 1998. - P. 25-34.

15. Gascoyne D. Hölderlin's Madness / David Gascoyne. - London : J. M. Dent, 1938. - 62 p.

16. Gascoyne D. Interview with Lucien Jenkins. Stand, Vol. 33, No. 2 (Spring 1992) // Selected Prose 1934-1996; [ed. R. Scott] / David Gascoyne. - London : Enitharmon Press, 1998. - P. 47-53.

17. Gascoyne D. Ramona Fotiade's Interview with David Gascoyne / David Gascoyne // International Quarterly. Disordered Houses: Surrealism and Beyond. - 1997. - Vol. 3. - No 1. - P. 20-23.

18. Gascoyne D. Arta Lucescu-Boutcher's Interview with David Gascoyne // Rediscovering Benjamin Fondane, A. Lucescu-Boutcher / David Gascoyne. - New York : Peter Lang, 2003. -P. 75-91.

19. Gascoyne D. Introducing Kenneth Patchen // Selected Prose 1934-1996; [ed. R. Scott] / David Gascoyne. - London : Enitharmon Press, 1998. - P. 164-170.

20. Gascoyne D. Introduction to A Short Survey of Surrealism / David Gascoyne. - San Francisco : City Lights Books, 1982. - P. vii-xiv.

21. Gascoyne D. Introduction to the Selected Poems of George Herbert // Poems by George Herbert; [ed. Gascoyne] / David Gascoyne. - Warwick : Greville Press, 2004. - P. 6-9.

22. Gascoyne D. A Kind of Declaratio / D. Gascoyne // Temenos. - 1981. - Vol. 1. - P. 155-169.

23. Gascoyne D. Léon Chestov // Existential Writings; [ed. R. Fotiade] / D. Gascoyne et al. - Oxford : Amaté Press, 2001. - P. 55-71.

24. Gascoyne D. Man's Life Is This Meat / David Gascoyne. - London : Parton Press, 1936. - 144 p.

25. Gascoyne D. Meetings with Benjamin Fondane // Existential Writings; [ed. R. Fotiade] / D. Gascoyne et al. - Oxford : Amaté Press, 2001. - P. 46-54.

26. Gascoyne D. Odeur de Pensée // New Collected Poems 1929-1995; [ed. R. Scott] / David Gascoyne. - London : Enitharmon P, 2014. - P. 158.

27. Gascoyne D. On the State of Poetry // Selected Prose 1934-1996; [ed. R. Scott] / David Gascoyne. - London : Enitharmon Press, 1998. - P. 63-70.

28. Gascoyne D. Preface to Benjamin Fondane's Le Mal des fantômes // Selected Prose 1934-1996; [ed. R. Scott] / David Gascoyne. London : Enitharmon Press, 1998. - P. 174-181.

29. Gascoyne D. Review of Angelos Sikelianos's Selected Poems // Selected Prose 1934-1996; [ed. R. Scott] / David Gascoyne. - London : Enitharmon Press, 1998. - P. 301-314. 
30. Gascoyne D. Roland Penrose, Recent Collages // Selected Prose 1934-1996; [ed. R. Scott] / David Gascoyne. - London : Enitharmon Press, 1998. - P. 186-188.

31. Gascoyne D. A Short Survey of Surrealism. $2^{\text {nd }}$ Edition with the Author's New Introduction / David Gascoyne. - San Francisco : City Lights, 1982. - 164 p.

32. Gascoyne D. A Short Survey of Surrealism / David Gascoyne. - London : Enitharmon Press, 2001. $-128 \mathrm{p}$.

33. Gascoyne D. The Sun at Midnight: Notes on the Story of Civilization Seen as the History of the Great Experimental Work of the Supreme Scientist. Aphorisms (Not yet in Proper Numbered Sequence), As from the Week-End in Amsterdam, May 2-4, 51969 / David Gascoyne. - London : Enitharmon Press, 1970. -55 p.

34. Gascoyne D. Sweeping the World's Surface // Selected Prose 1934-1996; [ed. R. Scott] / David Gascoyne. - London : Enitharmon Press, 1998. - P. 294-298.

35. Huelsenbeck R. En Avant Dada: a History of Dadaism // The Dada Painters and Poets: An Anthology; [ed. R. Motherwell \& J. Arp, transl. R. Manheim] / Robert Motherwell. - Harvard : Harvard University Press, 1989. - P. 21-47.

36. Hutcheon L. A Poetics of Postmodernism: History, Theory, Fiction / Linda Hutcheon. -London : Routledge, 1988. - 284 p.

37. Levi P. Review of David Gascoyne's Selected Poems / Peter Levi // Agenda. - 1994-1995. Vol. 32. - No 3-4 (Autumn-Winter). - P. 288.

38. Merrikin-Hill B. The Transparent Mirror / Brian Merrikin-Hill // Temenos. - 1986. - Vol. 7. P. 273-283.

39. Patchen K. Outlaw of the Lowest Planet / Kenneth Patchen. - London : Grey Walls Press, 1946. $-146 \mathrm{p}$.

40. Rémy M. David Gascoyne: "A Heart on Fire in the Snow" / Michel Rémy // Encrages. - 1989. - no 6 (Summer). - P. 30-31.

41. Rémy M. David Gascoyne ou l'urgence de l'inexprimé, suivi de notes sur les Collected Poems et du scénario inédit d'un film surréaliste / Michel Rémy. - Nancy : Presses Universitaires de Nancy, 1984. -200 p.

42. Rémy M. The Entrance of the Medium // A Short Survey of Surrealism, D. Gascoyne / Michel Rémy. - London : Enitharmon Press, 2001. - P. 13-22.

43. Rémy M. Surrealism in Britain / Michel Rémy. - Hants : Ashgate Publishing, 1999. - 404 p.

44. Rémy M. Surrealism's Vertiginous Descent on Britain // Angels of Anarchy and Machines for Making Clouds: Surrealism in Britain in the Thirties / Michel Rémy. - Leeds : Leeds City Art Galleries, 1986. - P. 19-55.

45. Rilke R. M. Archaic Torso of Apollo // The Selected Poetry of Rainer Maria Rilke, transl. by S. Mitchell / Rainer Maria Rilke. - New York : Vintage International, 1989. - P. 61.

46. Rouby B. Révolution et révélation: L'œuvre poétique de David Gascoyne / Bertrand Rouby. - Paris : Atelier national de reproduction de thèses, 1999. - $117 \mathrm{p}$.

47. Steiner G. Real Presences: Is There Anything in What We Say? / George Steiner. - London : Faber and Faber, 1989. - 326 p. 


\title{
ПОЕЗІЯ ЧИ РОЕ́SIE? ДЕВІД ГАСКОЙН ТА “КОНЦЕПЦІЯ ПОЕЗІї ЯК ЗАСОБУ ВИРАЖЕННЯ ДУХОВНОЇ ДІЯЛЬНОСТІ”
}

\section{Тобіаш Цвинар}

\author{
Варшавська політехніка \\ Пл. Політехніки, 1, Варшава, Польщча, 00-661 \\ Вшехнічу Польська школа вища в Варшаві \\ Пл. Дефіляд, 1, Варшава, Польщча, 00-901 \\ tobiaszcwynar@gmail.com
}

Стаття має на меті подати короткий вступ до інтерпретації природи, ролі та обсягу поезії у творчості Девіда Гаскойна. Описано основні риси поезії, яка бачиться не як ремесло чи звичайні засоби вираження, а радше як справжня духовна діяльність. Проаналізовано вплив на поетичну творчість Девіда Гаскойна дадаїстичних та сюрреалістичних теорій Андре Бретона. Звернено увагу на засадничу різницю у розумінні поезії в англійській та французькій національних традиціях та поєдняння самодецентрування та самотрансцедентності у творчості Девіда Гаскойна.

Ключові слова: сюрреалізм, модернізм, духовність, екзистенційний, екзистенціалізм. 